\title{
PENERAPAN MODEL PEMBELAJARAN DISCOVERY LEARNING UNTUK MENINGKATKAN KEMAMPUAN BERPIKIR KREATIF DAN HASIL BELAJAR SISWA
}

\author{
${ }^{1}$ Nichen Irma Cintia, ${ }^{2}$ Firosalia Kristin \& ${ }^{3}$ Indri Anugraheni \\ e-mail: 292014050@Student.uksw.edu \\ Universitas Kristen Satya Wacana
}

Jalan Diponegoro 52-60 Salatiga, Jawa Tengah

\begin{abstract}
Abstrak: Penelitian ini bertujuan untuk mengetahui dan mendeskripsikan model Discovery Learning dalam meningkatkan kemampuan berpikir kreatif dan hasil belajar siswa kelas 5 SDN Sidorejo Kidul 02 Tingkir. Penelitian ini dilaksanakan di SD Negeri Sidorejo Kidul 02 Kecamatan Tingkir pada tanggal 9-21 Maret 2018. Jenis Penelitian Tindakan Kelas (PTK) berlangsung dalam 2 siklus. Satu siklus terdiri dari empat tahap yaitu perencanaan, tindakan, observasi, dan refleksi. Subjek penelitian siswa kelas VSD berjumlah 39 siswa. Pengumpulan data menggunakan tes dan nontes. Analisis data deskriptif kuantitatif dan kualitatif. Kondisi awal persentase kemampuan berpikir kreatif 33,2\% skor rata-rata 13,3. Ketuntasan hasil belajar 38\% rata-rata 60 nilai tertinggi 72,5 dan terendah 45 . Siklus I, kemampuan berpikir kreatif siswa $73 \%$, skor rata-rata 29,2 . Persentase hasil belajar $71,8 \%$, rata-rata 69,48 , nilai tertinggi 82,5 dan terendah 50 . Siklus II, persentase kemampuan berpikir kreatif $81,2 \%$, rata-rata 32,2 . Hasil belajar $84,6 \%$, rata-rata 74,2, nilai tertinggi 87,5 dan terendah 55. Dapat disimpulkan bahwa penerapan model Discovery Learning dapat meningkatkan kemampuan berpikir kreatif dan hasil belajar pembelajaran tematik siswa kelas V SDN Sidorejo Kidul 02 Tingkir.
\end{abstract}

Kata-kata kunci: discovery learning, berpikir kreatif, hasil belajar

\section{THE IMPLEMENTATION OF DISCOVERY LEARNING MODEL IN INCREASING STUDENTS' THINKING CREATIVE ABILITY AND STUDENTS' LEARNING OUTCOME}

\begin{abstract}
The study aims to find and describe the model of Discovery Learning in increasing students' thinking creative ability and the results of five-grader student SD Negeri Sidorejo Kidul 02, Tingkir. The study was conducted in SD Negeri Sidorejo Kidul 02, Tingkir on 9 March, 2018. The type of the study which is Classroom Action Research (PTK) has done in 2 cycles. One cycle consists of four stages: planning, action, observation, and reflection. The total students of subjects of the five-grader research were 39 students. The study was used test and non test data collection. The study was used both quantitative and qualitative analysis. The initial condition percentage of creative thinking ability is $33.2 \%$ and the average score was 13.3. The completeness learning results were $38 \%$ with an average was 60, 72,5 for the highest score, 45 for the lowest score. Cycle I, students' creative thinking ability was $73 \%$, with an average score was 29,2 . Presentation of learning result was $71.8 \%$, an average score was $69.48,82.5$ for the highest score and 50 for the lowest score. Cycle II, percentage of creative thinking ability was $81.2 \%$, an average score was 32.2. The learrning result was in average of $74.2,87.5$ for the highest score and 55 for the lowest score. It can be concluded that the implementation of the Discovery Learning model can increase the ability of creative thinking and the learning outcomes of students' thematic learning for five-grader students in SDN Sidorejo Kidul 02 Tingkir.
\end{abstract}

Keywords: discovery learning, creative thinking, learning outcomes

\section{PENDAHULUAN}

Pendidikan memiliki peranan penting dalam perkembangan suatu bangsa. Pendidikan dapat menciptakan sumber daya manusia yang berkualitas (Anugraheni, 2017: 2016). Proses pendidikan dipengaruhi oleh beberapa faktor, diantaranya (1) input peserta didik; (2) sarana dan prasarana pendidikan; (3) bahan ajar; serta (4) sumber daya manusia (pendidiknya) yang dapat mendukung terciptanya suasana kondusif (Anugraheni, 2017: 247). Undang-Undang Republik Indonesia Nomor 20 Tahun 
2003 tentang sistem pendidikan nasional merumuskan tentang dasar, fungsi, dan tujuan pendidikan nasional. Pasal 2 Undang-Undang Negara Republik Indonesia Tahun 1945, bertujuan mengembangkan potensi peserta didik agar menjadi manusia yang beriman dan bertakwa kepada Tuhan Yang Maha Esa, berakhlak mulia, sehat, cakap, berilmu, kreatif, mandiri, dan menjadi warga negara yang demokratis, serta bertanggungjawab (Depdiknas, 2006: 28). Pembelajaran yang melibatkan keaktifan, kreativitas, kecakapan, hasil belajar, dan kemampuan berpikir kreatif siswa sesuai dengan sistem pendidikan nasional, hingga kini masih mengalami perkembangan, berbagai upaya pemerintah dilakukan untuk mengatasi permasalahan pendidikan seperti rendahnya keaktifan, kecakapan, kreativitas, hasil belajar, dan kemampuan berpikir kreatif yang dilatarbelakangi oleh pembelajaran yang bersifat konvensional dan teacher centered.

Kurikulum 2013 merupakan salah satu perubahan paradigma pembelajaran dari pembelajaran yang bersifat konvensional menjadi yang mengaktifkan siswa dan melatih kemampuan berpikir kreatif siswa. Kurikulum 2013 adalah kurikulum yang berbasis kompetensi, di dalamnya dirumuskan secara terpadu mencakup kompetensi sikap, pengetahuan, dan keterampilan yang harus dimiliki peserta didik. Dalam memudahkan pencapaian kompetensi yang dirumuskan dipilihlah pembelajaran tematik sebagai basis dalam pembelajaran (Indriasih, 2015: 128).

Pembelajaran tematik termasuk ke dalam pendekatan pembelajaran yang aktif, inovatif, kreatif, dan efektif, serta memadukan beberapa mata pelajaran. Pembelajaran tematik merupakan suatu sistem pembelajaran yang memungkinkan peserta didik baik individu maupun kelompok aktif mencari, menggali, mengeksplorasi, dan menemukan konsep (Mawardi, dkk, 2014: 2).

Kurikulum 2013 telah diterapkan di beberapa sekolah di Indonesia, khususnya di kota Salatiga, dalam penerapannya terdapat kendala dan masalah baik dalam penerapan ataupun dalam proses pembelajaran yang berlangsung, akibatnya tujuan dari Kurikulum 2013 belum tercapai secara maksimal. Kesulitan dalam penerapan Kurikulum 2013 adalah kebiasaan siswa yang terbiasa belajar menggunakan Kurikulum Tingkat Satuan Pendidikan (KTSP), siswa terbiasa belajar menggunakan pembelajaran yang bersifat konvensional, di dalam implementasi Kurikulum 2013, siswa diharapkan mampu belajar secara aktif dan kreatif namun dalam pelaksanaannya belum mendapatkan pembelajaran yang dapat melatih untuk belajar secara aktif dan kreatif, hal ini disebabkan sekolah belum sepenuhnya menerapkan model pembelajaran yang mengajak siswa untuk berpikir kreatif akhirnya implementasi dari pembelajaran Kurikulum 2013 belum tercapai secara optimal.

Berpikir kreatif menuntut seorang anak untuk memiliki kemampuan dalam memecahkan masalah, mempunyai variasi jawaban, memiliki kemampuan menguasai suatu konsep permasalahan, menyampaikan ide atau gagasan suatu topik permasalahan. Oleh sebab itu, berpikir kreatif menjadi salah satu kemampuan yang dikembangkan dalam Kurikulum 2013, sehingga berpikir kreatif sangat berpengaruh terhadap hasil belajar di mana hasil belajar biasanya dipengaruhi pemahaman siswa terhadap suatu konsep pembelajaran serta kemampuan siswa untuk memecahkan suatu permasalahan dalam proses pembelajaran.

Berdasarkan hasil observasi dan diskusi pada tanggal 21 September 2017 di SD Negeri Sidorejo Kidul 02 Kecamatan Tingkir, beberapa siswa kurang memahami pembelajaran tematik, tema 5 subtema 1 khususnya pada materi pencernaan hewan dan manusia. Kurangnya sarana media pembelajaran yang bersifat inovatif juga mempengaruhi proses pembelajaran, akhirnya pemahaman siswa terhadap konsep materi pembelajaran masih kurang. Selain itu, siswa kurang mandiri saat proses pembelajaran dan hanya menunggu perintah guru. Beberapa siswa merasa takut saat harus menuangkan ide dan pendapatnya, akhirnya kemampuan berpikir kreatif siswa sulit dikembangkan. Rendahnya kemampuan berpikir kreatif dan hasil belajar siswa juga diteliti oleh Erik R (2016) dan Mumin S \& Sri R (2018) yang menunjukkan rendahnya kemampuan berpikir kreatif dan hasil belajar dikarenakan metode pembelajaran masih bersifat konvensional, berpusat pada guru dan belum memberikan pengalaman langsung kepada siswa. Rendahnya pemahaman konsep siswa terhadap materi mempengaruhi hasil belajar siswa, sehingga nilai rata-rata siswa hanya 60 dan hanya ada 15 siswa mencapai KKM, sedangkan kemampuan berpikir kreatif siswa dalam proses pembelajaran hanya mencapai rata-rata 13,3 dengan presentase ketuntasan $32,2 \%$.

Dari uraian di atas, maka diperlukan tindakan dalam pembelajaran berupa penerapan model pembelajaran yang bersifat aktif. Dalam perkembangannya, model pembelajaran mempunyai banyak variasi, banyak model pembelajaran kreatif yang berpotensi meningkatkan kemampuan siswa dalam pembelajaran tematik. Salah satunya, model pembelajaran Discovery Learning, model ini digunakan 
untuk mengembangkan cara belajar aktif dengan menemukan sendiri, menyelidiki sendiri, maka hasil yang akan diperoleh bertahan lama dalam ingatan sehingga tidak mudah dilupakan oleh siswa (Kristin, 2016: 86). Model Discovery Learning menuntun siswa untuk mengidentifikasi apa yang ingin diketahui dengan mencari informasi sendiri, kemudian siswa mengorganisasi atau membentuk (konstruktif) apa yang diketahui dan dipahami ke dalam bentuk akhir.

Penelitian ini akan membahas bagaimana penerapan model pembelajaran Discovery Learning dalam meningkatkan kemampuan berpikir kreatif dan hasil belajar siswa, apakah penerapan model pembelajaran Discovery Learning dapat meningkatkan kemampuan berpikir kreatif dan hasil belajar siswa kelas 5 SD Negeri Sidorejo Kidul 02 Kecamatan Tingkir Kota Salatiga. Penelitian ini bertujuan untuk mendeskripsikan langkah-langkah model pembelajaran Discovery Learning dalam meningkatkan kemampuan berpikir kreatif dan hasil belajar siswa dan meningkatkan kemampuan berpikir kreatif serta hasil belajar siswa kelas 5 SD N Sidorejo Kidul 02 Kecamatan Tingkir Kota Salatiga melalui penerapan model pembelajaran Discovery Learning.

Discovery learning merupakan model yang mengarahkan siswa menemukan konsep melalui berbagai informasi atau data yang diperoleh melalui pengamatan atau percobaan. Menurut Sani (2014: 97-98), discovery learning merupakan proses dari inkuiri. Discovery learning adalah metode belajar yang menuntut guru lebih kreatif menciptakan situasi yang membuat peserta didik belajar aktif dan menemukan pengetahuan sendiri. Maharani \& Hardini (2017: 552), discovery learning adalah proses pembelajaran yang penyampaian materinya tidak utuh, karena model discovery learning menuntut siswa terlibat aktif dalam proses pembelajaran dan menemukan sendiri suatu konsep pembelajaran.

Ciri utama model discovery learning adalah (1) berpusat pada siswa; (2) mengeksplorasi dan memecahkan masalah untuk menciptakan, menghubungkan, dan menggeneralisasi pengetahuan; serta (3) kegiatan untuk menggabungkan pengetahuan baru dan pengetahuan yang sudah ada (Kristin, 2016: 92).

Darmadi (2017: 113-114) menyebutkan langkahlangkah pengaplikasian model discovery learning yaitu (1) menentukan tujuan pembelajaran; (2) melakukan identifikasi karakteristik siswa; (3) menentukan materi pelajaran; (4) menentukan topik-topik yang harus dipelajari siswa secara induktif; (5) mengembangkan bahan-bahan dengan memberikan contoh, ilustrasi, tugas, dan sebagainya untuk dipelajari siswa; (6) mengatur topik-topik pelajaran berawal dari yang sederhana ke yang kompleks, dari yang konkret ke abstrak, dan dari tahap enaktif, ikonik sampai ke tahap simbolik; serta (7) melakukan penilaian proses dan hasil belajar siswa. Syah (dalam Darmadi, 2017: 114-117) terdapat prosedur yang harus digunakan dalam mengaplikasikan model discovery learning, yaitu (a) stimulation (pemberian rangsangan); (b) problem statement (identifikasi masalah); (c) data collection (pengumpulan data); (d) data processing (pengolahan data); (e) verification (pembuktian); dan (f) generalization (menarik kesimpulan).

Berpikir kreatif adalah proses berpikir yang menghasilkan berbagai macam kemungkinan jawaban (Siswono \& Novitasari, 2015: 2). Berpikir kreatif terkait dengan pemikiran kritis. Pemikiran kritis adalah pemikiran yang sangat jauh dan mendalam, sedangkan berpikir kreatif adalah pemikiran yang sederhana. Berpikir kreatif tampak jelas dalam upaya penemuan, menuntut fleksibilitas dan bergantung pada keberagaman, sehingga berpikir kreatif menyerupai pemecahan masalah seperti usaha mencapai produksi kreatif.

Berpikir kreatif mencakup kebiasaan-kebiasaan dalam berpikir, diantaranya (1) ikut memberikan perhatian ke dalam berbagai kepentingan, terutama ketika belum ditemukan jawaban atau solusi dengan segera; (2) menghilangkan batasan-batasan antara wawasan dan taksiran; (3) melahirkan, memelihara, dan mengabadikan tingkat standarisasi; (4) menciptakan cara baru untuk melihat prinsip-prinsip luar dan batasan-batasan tradisional yang diikuti (Al-Khalili, 2005: 37-39). Menurut Silver (dalam Siswono, 2004: 3) terdapat empat indikator berpikir kreatif, yaitu (1) fluence (kemampuan menghasilkan banyak ide); (2) flexibility (kemampuan menghasilkan ide-ide yang bervariasi); (3) originality (kemampuan menghasilkan ide baru atau ide yang sebelumnya tidak ada); serta (4) elaboration (kemampuan mengembangkan atau menambahkan ide-ide sehingga dihasilkan ide yang rinci atau detail.

Hasil belajar adalah kemampuan yang dimiliki peserta didik setelah melewati proses belajar (Septiyani \& Rosnita, 2018: 4), sedangkan menurut Kristin (2016: 92), hasil belajar adalah puncak dari keberhasilan belajar peserta didik terhadap tujuan belajar yang telah ditetapkan, hasil belajar peserta didik dapat meliputi aspek kognitif (pengetahuan), afektif (sikap), dan psikomotorik (tingkah laku).

Berdasarkan pendapat di atas, hasil belajar merupakan kemampuan baru yang dimiliki oleh 
peserta didik yang didapatkan setelah melewati proses belajar sesuai dengan tujuan belajar yang telah ditetapkan mencakup aspek kognitif, afektif, dan psikomotorik.

Hasil belajar merupakan proses yang cukup kompleks, hasil belajar siswa dipengaruhi oleh beberapa faktor yang mendukung, yaitu (1) faktor internal, meliputi faktor fisiologis dan psikologis; dan (2) faktor eksternal, meliputi faktor lingkungan sosial dan nonlingkungan sosial, peran siswa, peran guru, serta model yang digunakan dalam pembelajaran (Widayanti \& Slameto, 2016: 187).

Tugas pokok tenaga kependidikan adalah mengevaluasi taraf keberhasilan kegiatan belajar secara tepat (valid) dan dapat dipercaya (reliable). Menurut Anugraheni (2017: 249-250), keberhasilan proses pembelajaran tergantung pada tingkat ketepatan, keobjektifan, kepercayaan, dan informasi yang representative. Hasil belajar siswa dapat diukur dengan menggunakan tes hasil belajar atau tes prestasi belajar ataupun achievement test. Tes hasil belajar ini biasanya disusun dan dibuat sendiri oleh guru. Hasil belajar juga tidak lepas dengan proses belajar.

\section{METODE PENELITIAN}

Penelitian ini berlangsung selama 2 siklus, siklus I dilaksanakan pada tanggal 9-12 Maret 2018 dan siklus II dilaksanakan pada tanggal 19-21 Maret 2018. Penelitian ini menggunakan Penelitian Tindakan Kelas (PTK). Penelitian tindakan kelas merupakan suatu upaya untuk menjelaskan berbagai aspek dari hubungan antar ketergantungan materi, subjek, pembelajar, dan pengajar sehubungan dengan isu totalitas dan logika internal dari tugas sosial mengkontruksi pengetahuan dari PBM (Slameto, 2015: 148). Prosedur penelitian tindakan kelas pada penelitian ini didasarkan dari pendekatan yang dikembangkan oleh Lewin yang terdiri atas perencanaan, tindakan, pengamatan, dan refleksi (Arikunto, 2008: 92).

Teknik yang digunakan untuk mengumpulkan data pada penelitian ini disesuaikan dengan jenis data yang diambil, yaitu (1) observasi, merupakan pengamatan atau pencatatan kegiatan yang dilakukan dengan sistematis, bertujuan untuk mengamati perilaku dan aktivitas selama proses pembelajaran berlangsung; (2) rubrik, menggambarkan kriteria dari penilaian yang digunakan untuk menilai atau memberi tingkatan dari hasil pekerjaan siswa; (3) tes, untuk mengukur hasil belajar siswa; dan (4) dokumentasi, pengambilan gambar oleh peneliti untuk memperkuat data yang diperoleh dalam kegiatan pembelajaran.

Teknik analisis data yang digunakan dalam penelitian ini adalah teknik deskriptif kuantitatif dan kualitatif. Data yang didapatkan dari hasil tes yang berbentuk uraian dan pilihan ganda adalah data kuantitatif. Data ini disajikan dalam bentuk angka sedangkan data kualitatif adalah data yang berasal dari hasil lembar observasi atau chekclist guru dan siswa berupa suatu penjelasan atau keterangan. Untuk menjamin instrumen soal pilihan ganda dan isian dalam penelitian ini maka dilakukan uji validitas dan uji reliabilitas. Instrumen soal yang baik harus memenuhi syarat yaitu, valid dan reliabel.

\section{HASIL DAN PEMBAHASAN}

\section{Hasil Kemampuan Berpikir Kreatif dan Hasil Belajar}

Sebelum dilaksanakannya siklus I dan siklus II, peneliti terlebih dahulu melakukan observasi dan diskusi dengan guru kelas V SD Negeri Sidorejo Kidul 02 Kecamatan Tingkir, untuk mengetahui keadaan siswa dalam proses pembelajaran serta melihat bagaimana cara guru dalam menyampaikan materi pembelajaran. Dengan dilakukan observasi dan diskusi, peneliti mengetahui bagaimana keadaan awal kegiatan pembelajaran sebelum dilakukan tindakan dengan menggunakan model pembelajaran discovery learning. Dari hasil observasi ternyata proses pembelajaran belum memberikan pengalaman langsung kepada siswa. Kegiatan pembelajaran yang dilakukan didominasi dengan pemberian materi secara teoretis dan keterbatasan media dalam proses pembelajaran, sehingga siswa menjadi ramai, kurang memperhatikan materi, pasif dan kurang tertarik dengan pembelajaran tematik. Hal ini menyebabkan kurangnya pemahaman siswa terhadap konsep materi yang diberikan sehingga berdampak pada kemampuan berpikir kreatif dan hasil belajar.

Berdasarkan hasil observasi dan diskusi serta penelitian yang telah dilakukan oleh peneliti, dapat dilihat nilai pra siklus, siklus I, dan siklus II kemampuan berpikir kreatif dan hasil belajar pembelajaran tematik siswa kelas V SD Negeri Sidorejo Kidul 02 Kecamatan Tingkir sebagai berikut.

Tabel 1

Data Kemampuan Berpikir Kreatif Pra Siklus, Siklus I, dan Siklus II

\begin{tabular}{lccc}
\hline Indikator & $\begin{array}{c}\text { Pra } \\
\text { siklus }\end{array}$ & $\begin{array}{c}\text { Siklus } \\
\text { I }\end{array}$ & $\begin{array}{c}\text { Siklus } \\
\text { II }\end{array}$ \\
\hline Jumlah siswa & 39 & 39 & 39 \\
\hline
\end{tabular}




\begin{tabular}{lccc}
\hline \multicolumn{1}{c}{ Indikator } & $\begin{array}{c}\text { Pra } \\
\text { siklus }\end{array}$ & $\begin{array}{c}\text { Siklus } \\
\text { I }\end{array}$ & $\begin{array}{c}\text { Siklus } \\
\text { II }\end{array}$ \\
\hline Jumlah skor & 93 & 392 & 441 \\
Rata-rata skor & 13,3 & 29,20 & 32,5 \\
Skor tertinggi & 18 & 62 & 71 \\
Skor terendah & 10 & 45 & 56 \\
Presentase siswa berpikir kreatif & $33,2 \%$ & $73 \%$ & $81,5 \%$ \\
$\begin{array}{l}\text { Presentase siswa belum berpikir } \\
\text { kreatif }\end{array}$ & $66,8 \%$ & $25 \%$ & $18,5 \%$ \\
\hline
\end{tabular}

Tabel 1 menunjukkan bahwa skor kemampuan berpikir kreatif siswa pada pra siklus hanya mencapai rata-rata 13,3 dengan persentase ketuntasan 33,2\%. Pada siklus I, kemampuan berpikir kreatif siswa mengalami peningkatan 39,8\% sedangkan pada siklus II kemampuan berpikir kreatif siswa mengalami peningkatan sebesar $8,12 \%$.

Tabel 2

Data Hasil Nilai Pra Siklus, Siklus I dan Siklus II

\begin{tabular}{lccc}
\hline \multicolumn{1}{c}{ Indikator } & Pra & Siklus & Siklus \\
& Siklus & I & II \\
\hline Jumlah siswa & 39 & 39 & 39 \\
Jumlah nilai & 2.340 & 2.750 & $2.902,5$ \\
Rata-rata & 60 & 69,5 & 74,4 \\
Nilai tertinggi & 72,5 & 82,5 & 87,5 \\
Nilai terendah & 45 & 50 & 55 \\
Presentase siswa tuntas & $38,5 \%$ & $71,8 \%$ & $84,6 \%$ \\
Presentase siswa tidak & $61,5 \%$ & $28,2 \%$ & $15,4 \%$ \\
tuntas & & & \\
\hline
\end{tabular}

Berdasarkan Tabel 2 dapat diuraikan bahwa sebelum dilakukan tindakan dari 39 siswa terdapat 15 siswa yang tuntas dan 24 siswa tidak tuntas, dengan melihat nilai siswa tertinggi yaitu 72,5 dan terendah 45. Pada siklus I, hasil belajar siswa mengalami peningkatan $33 \%$, sedangkan pada siklus II, hasil belajar siswa mengalami kenaikan sebesar $12,8 \%$.

\section{Siklus I}

\section{Proses pembelajaran}

Pada tahap perencanaan (planning), peneliti mempersiapkan rencana tindakan untuk meningkatkan kemampuan berpikir kreatif dan hasil belajar pada Tema 6 Panas dan Perpindahannya, Subtema 2 Perpindahan Kalor di Sekitar Kita, Pembelajaran 2 dan 5 dengan menggunakan model discovery learning. Langkah-langkah perencanaannya meliputi (1) menentukan permasalahan yang akan dibahas; (2) merancang proses pembelajaran model discovery learning menggunakan media sesuai dengan materi yang akan diajarkan; (3) menyusun Rencana Pelaksanaan Pembelajaran (RPP), lembar kerja siswa, lembar observasi, rubrik penilaian, bahan ajar, dan alat evaluasi. Rencana Pelaksanaan Pembelajaran (RPP) memuat Kompetensi Inti (KI) dan kompetensi dasar; dan (4) konsultasi dengan guru kelas tentang Rencana Pelaksanaan Pembelajaran (RPP), lembar kerja siswa, lembar observasi, rubrik penilaian, media pembelajaran, dan alat evaluasi.

Pada tahap pelaksanaan (acting) siklus I dilaksanakan dalam tiga kali pertemuan dengan alokasi waktu 3 jam pelajaran ( $8 \times 35$ menit). Pertemuan I dilaksanakan pada Jum'at 9 Maret 2018 pukul 07.0008.45 WIB, pertemuan II dilaksanakan pada Sabtu 10 Maret 2018 pukul 09.00-10.45 WIB, dan pertemuan III dilaksanakan pada Senin 12 Maret 2018 pukul 07.0008.10 WIB.

Pada tahap observasi (observing) dilakukan oleh teman sejawat menggunakan lembar observasi dan dilaksanakan saat pelaksanaan pembelajaran. Dari lembar observasi diperoleh bahwa guru sudah melaksanakan pembelajaran dengan runtut dan melibatkan siswa dalam penerapan model pembelajaran discovery learning, namun saat proses identifikasi data dan analisis permasalahan yang dihadapi siswa masih merasa bingung. Pada saat percobaan, beberapa siswa asyik bermain menggunakan media percobaan sehingga penguasaan kelas kurang. Pengamatan siswa pada saat kegiatan pembelajaran belum sesuai dengan yang diharapkan peneliti, dimana siswa dapat belajar secara aktif dengan menyelidiki sendiri, menemukan sendiri, dan mengkonsepkan pemahaman materi sehingga materi pembelajaran dapat diingat dan dipahami siswa dengan baik. Siswa belum mampu mencari alternatif jawaban dan makna dari percobaan yang dilakukan karena siswa terbiasa melakukan sesuatu berdasarkan perintah dan aba-aba guru, siswa belum berani menuangkan ide dan gagasannya karena belum terbiasa menggunakan model discovery learning.

Pada tahap refleksi (reflecting) siklus I, dapat disimpulkan selama guru mengajar siswa kurang memahami materi yang diajarkan oleh guru, siswa merasa malu dan takut untuk mengeluarkan ide dan gagasannya, serta harus ditunjuk saat menyampaikan hasil diskusi kelompoknya. Hal ini dikarenakan beberapa materi kurang dilihat siswa secara leluasa, sehingga siswa yang duduk di belakang kurang mampu memahami materi tersebut, kurang percaya diri dengan pendapatnya sehingga merasa takut dan malu untuk menyampaikan ide dan pendapatnya. Guru harus bisa menyampaikan materi secara menyeluruh, mengontrol, dan menguasai kelas agar siswa dapat fokus pada pembelajaran dan tidak ramai sendiri. Guru harus membuat siswa untuk 
belajar aktif menyelidiki sendiri, menemukan sendiri, melalui belajar penemuan siswa dapat berpikir kreatif, analisis, dan mencoba memecahkan sendiri masalah yang dihadapi.

\section{Kemampuan berpikir kreatif siklus I}

Tabel 1 menunjukkan adanya peningkatan dari 7 kelompok siswa. Skor total pertemuan adalah 190 , rata-rata skor 27 , persentase $67,8 \%$ dengan skor tertinggi 30 dan skor terendah 19. Skor total pertemuan II dari 7 kelompok adalah 202, rata-rata skor 28,8 dengan persentase sebesar $72,1 \%$, jumlah skor tertinggi 32 dan skor terendah 26. Total skor siklus I adalah 392, dengan jumlah skor tertinggi dari dua pertemuan 62, sedangkan skor terendahnya adalah 45. Rata-rata skor 29,2 dengan persentase 73\%. Persentase kelompok yang belum mencapai ketuntasan adalah 27\% dan akan diperbaiki melalui perbaikan di siklus II.

\section{Hasil belajar siklus I}

Berdasarkan Tabel 2, hasil belajar siswa pada siklus I pertemuan III menunjukkan adanya peningkatan dari 39 siswa. Persentase ketuntasan siswa mengalami peningkatan sebesar $41,8 \%$ dengan persentase sebesar $71,8 \%$ dari 28 siswa yang ada, sedangkan untuk siswa yang tidak tuntas yaitu sebesar 28,20\% dari 11 siswa. Kelompok yang belum mencapai KKM, akan diperbaiki melalui perbaikan di siklus II.

\section{Siklus II}

\section{Proses pembelajaran}

Pada tahap perencanaan (planning), peneliti mempersiapkan rencana tindakan untuk meningkatkan kemampuan berpikir kreatif dan hasil belajar Tema 6 Panas dan Perpindahannya Subtema 3 Pengaruh Kalor terhadap Kehidupan, Pembelajaran 2 dan 5 menggunakan model discovery learning. Berikut ini adalah langkah perencanaannya (a) menentukan permasalahan yang akan dibahas; (b) merancang proses pembelajaran model discovery learning menggunakan media sesuai dengan materi yang akan diajarkan; (c) menyusun Rencana Pelaksanaan Pembelajaran (RPP), lembar kerja siswa, lembar observasi, rubrik penilaian, bahan ajar, dan alat evaluasi. Rencana Pelaksanaan Pembelajaran (RPP) memuat Kompetensi Inti (KI) dan kompetensi dasar; dan (d) konsultasi dengan guru kelas tentang Rencana Pelaksanaan Pembelajaran (RPP), lembar kerja siswa, lembar observasi, rubrik penilaian, media pembelajaran, dan alat evaluasi.

Pada tahap pelaksanaan (acting), siklus II dilaksanakan dalam tiga kali pertemuan alokasi waktu 3 jam pelajaran (8×35 menit). Pertemuan I dilaksanakan pada Senin 19 Maret 2018 pukul 09.0010.45 WIB, pertemuan II dilaksanakan pada Selasa 20 Maret 2018 pukul 07.00-08.10 WIB, dan pertemuan III dilaksanakan pada Rabu 21 Maret 2018 pukul 07.0008.10 WIB.

Pada tahap observasi (observing) dilakukan oleh teman sejawat menggunakan lembar observasi saat pelaksanaan pembelajaran. Berdasarkan hasil lembar observasi dapat dilihat hasil kegiatan pembelajaran dengan menerapkan model discovery learning. Hasil observasi yang diperoleh siklus II kegiatan pembelajaran mengalami peningkatan dibandingkan pada pertemuan siklus I. Hal ini dikarenakan guru sudah menggunakan model pembelajaran discovery learning dengan maksimal, menguasai kelas, dan menggunakan media dengan benar didukung media power point untuk penyampaian materi sehingga siswa mampu memahami materi dengan baik, siswa terlihat bersemangat dan aktif saat proses pembelajaran. Siswa sudah terbiasa dengan penerapan model discovery learning, siswa sudah terbiasa untuk menyelidiki sendiri, menemukan sendiri jawaban atas permasalahan yang diberikan oleh guru sehingga siswa lebih memperhatikan proses percobaan untuk mengetahui jawaban atas permasalahan yang diberikan oleh guru sehingga tertarik dengan pembelajaran hal ini membuat siswa berani untuk menuangkan ide dan pendapatnya masing-masing.

Pada tahap refleksi (reflecting) berdasarkan observasi pertemuan pertama, pertemuan kedua, dan pertemuan ketiga pada siklus II dapat dikatakan sudah baik dan kondusif sesuai dengan harapan peneliti. Dalam kegiatan pembelajaran, siswa dapat dikatakan baik karena terlaksananya langkah-langkah pada pelaksanaan pembelajaran menggunakan model pembelajaran discovery learning, sehingga ada peningkatan pada kemampuan berpikir kreatif siswa dan hasil belajar siswa dibandingkan sebelumnya.

\section{Kemampuan berpikir kreatif siklus II}

Tabel 1 menunjukkan adanya peningkatan dari 7 kelompok siswa. Skor total pertemuan pertama adalah 211, rata-rata skor 30,1, dengan presentase $75,3 \%$, skor tertinggi 34 dan skor terendah 27 . Skor total pertemuan II dari 7 kelompok adalah 230, rata-rata skor 32,8 dengan presentase sebesar $82,1 \%$. Skor tertinggi 37 , skor terendah 29. Total skor siklus II adalah 441, dengan jumlah skor tertinggi dari dua pertemuan 71 , skor terendah 56. Rata-rata skor 32,5\% dengan presentase $81,2 \%$, kelompok yang belum mencapai ketuntasan adalah 18,8\% dan akan diperbaiki melalui perbaikan pembelajaran berikutnya. Pada penelitian yang dilakukan oleh Erik R. (2016), kemampuan berpikir kreatif siswa mengalami kenaikan sebesar 71,55 hal ini menunjukkan bahwa model discovery learning dapat meningkatkan kemampuan berpikir 
kreatif siswa.

\section{Hasil belajar siklus II}

Berdasarkan tabel 2, hasil belajar siswa yang diperoleh pada siklus I pada pertemuan III menunjukkan adanya peningkatan dari 39 siswa, persentase ketuntasan siswa mengalami peningkatan sebesar $12,8 \%$ dengan persentase sebesar $84,6 \%$ dari 28 siswa yang ada, sedangkan persentase bagi yang tidak tuntas sebesar $15,4 \%$ dari 5 siswa. Kelompok yang belum mencapai KKM akan diperbaiki melalui perbaikan pembelajaran berikutnya. Pada penelitian yang dilakukan oleh Mumin S \& Sri R (2016), di mana siklus I mencapai rata-rata 80,4\% hal ini menunjukkan bahwa model discovery learning dapat meningkatkan hasil belajar siswa.

Perbandingan kemampuan berpikir kreatif kondisi awal siklus I dan II

Berikut dapat dilihat grafik kemampuan berpikir kreatif pembelajaran tematik pra siklus, siklus I dan siklus II :

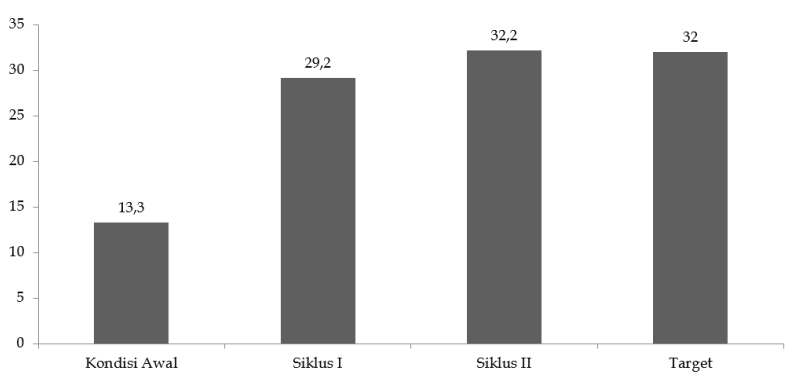

Gambar 1. Perbandingan kemampuan berpikir kreatif kondisi awal siklus I dan siklus 2

Berdasarkan grafik perbandingan kemampuan berpikir kreatif pembelajaran tematik siswa kelas V SD Negeri Sidorejo Kidul 02 Kecamatan Tingkir mengalami peningkatan dari pra siklus dengan persentase sebesar $33,2 \%$, rata-rata 13,3 , siklus I persentase $73 \%$ dengan rata-rata 29,2 sedangkan pada siklus II persentase sebesar 81,2\% rata-rata 32,2 dari 7 kelompok. Siswa dikatakan mengalami peningkatan berpikir kreatif apabila mengalami peningkatan sebanyak $80 \%$, rata-rata skor 32 . Hal ini menunjukkan bahwa dengan menggunakan model discovery learning dapat meningkatkan kemampuan berpikir kreatif siswa di mana pada siklus II ketuntasan siswa mencapai 81,2\% dengan rata-rata 32,2.

Perbandingan hasil belajar kondisi awal siklus I dan siklus II

Berikut dapat dilihat grafik hasil belajar pembelajaran tematik pra siklus, siklus I dan siklus II :

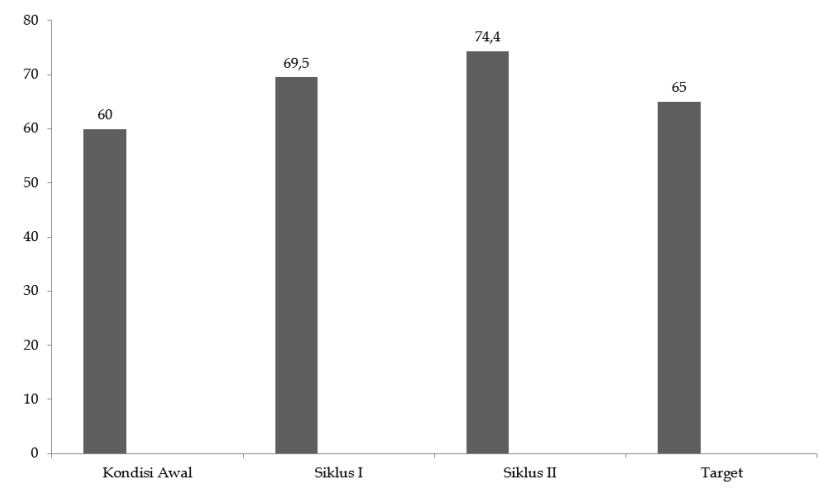

Gambar 2. Perbandingan hasil belajar pembelajaran tematik kondisi awal, siklus I dan siklus II

Berdasarkan diagram di atas perbandingan hasil belajar pembelajaran tematik siswa kelas $\mathrm{V}$ SD Negeri Sidorejo Kidul 02 Kecamatan Tingkir mengalami peningkatan dari rata-rata pra siklus 60, dengan persentase ketuntasan 38\%. Pada siklus I menjadi 69,5 dengan persentase ketuntasan sebesar $71,8 \%$, sedangkan pada siklus II rata-rata 74,16, dengan persentase ketuntasan sebesar 84,6\%. Jumlah siswa yang tuntas KKM 65 semakin meningkat. Pada pra siklus siswa yang tidak tuntas 24 , pada siklus I siswa yang tidak tuntas 11, dan siklus II siswa yang tidak tuntas 5 dari jumlah siswa 39. Hasil belajar siswa dikatakan meningkat apabila $80 \%$ siswa mengalami ketuntasan $\geq 65$ dengan KKM 65 .

\section{Analisis Data}

Sebelum dilakukan tindakan, skor rata-rata kemampuan berpikir kreatif siswa adalah 13,3 dengan persentase 33,25\%. Hasil belajar siswa sebelum dilakukan tindakan dari 39 siswa, terdapat 15 siswa yang tuntas dan 24 siswa yang tidak tuntas. Dengan melihat nilai siswa tertinggi yaitu 72,5 dan nilai terendah 45. Dari hasil observasi dan diskusi, rendahnya hasil belajar dan kemampuan berpikir kreatif siswa pada pembelajaran tematik siswa kelas V SD Negeri Sidorejo Kidul 02 Kecamatan Tingkir adalah belum adanya proses pembelajaran yang memberikan pengalaman langsung kepada siswa saat proses pembelajaran. Pemberian materi masih bersifat teoretis dengan media yang terbatas dalam proses pembelajaran, sehingga siswa kesulitan dalam mengkonsepkan materi, ramai, dan kurang tertarik dengan pembelajaran tematik. Siswa belum belajar secara aktif dan berdampak pada kemampuan berpikir kreatif dan hasil belajar siswa pada pembelajaran tematik yang berdampak pada rendahnya nilai rata-rata siswa yaitu 60 dari KKM. Oleh sebab itu, peneliti melakukan perbaikan pembelajaran tematik dengan menerapkan model pembelajaran discovery 
learning dengan bantuan media pembelajaran untuk meningkatkan pemahaman dan penguasaan konsep siswa pada Tema 6 Panas dan Perpindahannya Subtema 2 Perpindahan Kalor di Sekitar Kita dan Subtema 3 Pengaruh Kalor terhadap Kehidupan, yang dilakukan pada siklus I dan siklus II dengan masingmasing siklus terdiri dari tiga kali pertemuan.

Adanya perbandingan antara jumlah siswa yang tuntas dan belum tuntas serta skor rata-rata dan persentase kemampuan berpikir kreatif siswa dikarenakan siswa yang tuntas memahami materi yang diberikan guru, sedangkan siswa yang belum tuntas belum mampu memahami materi yang diberikan guru dengan sepenuhnya. Pemahaman konsep kemampuan berpikir kreatif dan hasil belajar didapatkan dari siklus I dan siklus II. Siklus I menunjukkan adanya peningkatan kemampuan berpikir kreatif siswa dengan skor rata-rata 29,2 dengan persentase $73 \%$. Hasil belajar siswa mengalami peningkatan. Dari 39 siswa, siswa yang tuntas sebesar $71,8 \%$ atau 28 siswa dari 39 siswa. Siswa yang tidak tuntas sebesar 28,2\% atau 11 siswa. Pada siklus II menunjukkan peningkatan kemampuan berpikir kreatif siswa dengan skor ratarata 32,2 dengan presentase 81,2\%. Hasil belajar siswa meningkat dari siklus I ke siklus II. Dari 39 siswa, siswa yang tuntas sebesar 84,6\% atau 31 siswa dari 39 siswa yang ada. Siswa yang tidak tuntas yaitu $15,4 \%$ atau 5 siswa dari 39 siswa.

\section{Pembahasan}

Keberhasilan peningkatan kemampuan berpikir kreatif dan hasil belajar dikarenakan penerapan model pembelajaran discovery learning yang dilakukan sesuai dengan sintak. Menurut Wahyudi \& Siswanti (2015: 27), discovery learning merupakan proses pembelajaran di mana siswa tidak disajikan pelajaran dalam bentuk finalnya, tetapi diharapkan siswa mengorganisasi sendiri, discovery learning lebih menekankan pada penemuan konsep atau prinsip yang sebelumnya tidak diketahui. Menurut Hanifah \& Wasitohadi (2017: 95), discovery learning merupakan rangkaian kegiatan pembelajaran yang melibatkan siswa untuk belajar aktif menemukan pengetahuan sendiri. Dengan belajar penemuan, siswa dapat berpikir analisis dan mencoba untuk memecahkan sendiri masalah yang dihadapi.

Berdasarkan hasil analisis data, model discovery learning dapat meningkatkan kemampuan berpikir kreatif dan hasil belajar siswa. Kemampuan berpikir kreatif siswa awalnya hanya mencapai 33,2\%, dengan rata-rata 13,3 dari 7 kelompok, kemudian mengalami peningkatan sebesar 39,8\% pada siklus I menjadi 73\%, dengan rata-rata 29,2. Pada siklus II juga mengalami peningkatan sebesar $8,2 \%$ menjadi $81,2 \%$, dengan rata- rata 32,2 melebihi indikator keberhasilan yang ingin dicapai yaitu rata-rata 32 , dengan persentase $80 \%$.

Hasil belajar siswa awalnya hanya mencapai rata-rata 60 dengan persentase 38,5\%. Siklus I mengalami peningkatan, rata-rata siswa menjadi 69,5 dengan kenaikan persentase sebesar 33\% menjadi $71,8 \%$. Pada siklus II rata-rata menjadi 74,4 mengalami kenaikan persentase sebesar $12,8 \%$ menjadi $84,6 \%$. Hasil belajar yang diperoleh melebihi indikator keberhasilan yang ditentukan. Hasil belajar siswa dikatakan meningkat apabila $80 \%$ siswa mengalami ketuntasan $\geq 65$ dengan KKM 65 .

Berdasarkan pendapat Wahyudi \& Siswanti (2015), discovery learning merupakan pelajaran yang disajikan dengan tidak utuh untuk meningkatkan kemampuan penemuan pada siswa. Pendapat ini sejalan dengan pendapat Hanifah \& Wasitohadi (2017) bahwa discovery learning merupakan model pembelajaran yang mengajak siswa belajar aktif menemukan sendiri pengetahuannya, hal itu akan membuat siswa merasa tertantang dan tertarik untuk mengidentifikasi permasalahan dengan suatu percobaan, sehingga siswa akan merasa tertarik untuk memahai materi dan menguasai materi pembelajaran tematik. Peneliti lain yang dapat membuktikan meningkatnya kemampuan berpikir kreatif dan hasil belajar siswa dengan menerapkan model discovery learning adalah Erik $\mathrm{R}$ (2014). Kemampuan berpikir kreatif siswa mencapai ketuntasan dengan nilai rata-rata 71,55. Hasil belajar siswa dapat dilihat dari hasil penelitian Mumin S dan Sri R (2017) yang menghasilkan, pada siklus I hasil belajar siswa mencapai persentase ketuntasan sebesar 54,6, sedangkan pada siklus II mencapai persentase ketuntasan sebesar 80,9\%, dan siklus III mencapai persentase ketuntasan sebesar 91,8\%.

Berdasarkan penelitian yang telah dilakukan oleh beberapa peneliti menunjukkan bahwa model discovery learning mampu meningkatkan kemampuan berpikir kreatif dan hasil belajar siswa. Namun dari dua penelitian tersebut memiliki beberapa kekurangan sehingga diperbaiki pada penelitian ini. Penelitian ini memiliki keunggulan, yaitu (1) menekankan dua aspek sekaligus, yaitu berpikir kreatif dan hasil belajar; dan (2) penelitian ini menggunakan media yang ada di lingkungan sekitar siswa dan menggunakan permasalahan yang ada di sekitar kehidupan siswa, sehingga penelitian ini dapat meningkatkan kemampuan berpikir kreatif dan hasil belajar pada Tema 6 Panas dan Perpindahannya Subtema 2 Perpindahan Kalor di Sekitar Kita dan Subtema 3 Pengaruh Kalor terhadap Kehidupan, pada akhirnya 
dapat meningkatkan kemampuan berpikir kreatif dan hasil belajar pembelajaran Tematik siswa kelas V SD Negeri Sidorejo Kidul 02 Kecamatan Tingkir Semester II Tahun Pelajaran 2018.

\section{PENUTUP}

\section{Kesimpulan}

Dari hasil pembahasan di atas, dapat disimpulkan bahwa terdapat peningkatan kemampuan berpikir kreatif dan hasil belajar siswa pada pembelajaran tematik kelas V SD Negeri Sidorejo Kidul 02 Kecamatan Tingkir Semester II Tahun Ajaran 2017. Hal ini dibuktikan dari kemampuan berpikir kreatif dan hasil belajar siswa pada pra siklus. Pada pra siklus, kemampuan berpikir kreatif siswa hanya mencapai persentase 33,25\% dengan rata-rata 13,3 dari 7 kelompok siswa, sedangkan hasil belajar siswa pada pra siklus 15 siswa tuntas dengan persentase $38 \%$. Kemudian pada siklus I, kemampuan berpikir kreatif siswa meningkat, mencapai persentase $73 \%$ dengan rata-rata 29,2 dari 7 kelompok, sedangkan hasil belajar siswa pada siklus I mencapai 28 siswa yang tuntas dengan persentase $71,8 \%$. Selanjutnya, pada siklus II, kemampuan berpikir kreatif siswa semakin meningkat, mencapai persentase $81,2 \%$ dengan rata-rata 32,2 dari 7 kelompok, sedangkan untuk hasil belajar siswa meningkat menjadi 31 siswa yang tuntas dengan persentase $84,6 \%$ dan yang tidak tuntas sebanyak 5 siswa dengan persentase $15,4 \%$ dari 39 siswa.

\section{Saran}

Berdasarkan hasil penelitian di kelas $\mathrm{V}$ SD Negeri Sidorejo Kidul 02 Kecamatan Tingkir Kabupaten Semarang Semester II Tahun Pelajaran 2018, dapat disarankan (1) guru lebih membimbing siswa saat proses pembelajaran terutama pada tahap percobaan sehingga percobaan dapat berjalan dengan baik; (2) pembelajaran dengan menggunakan model discovery learning dapat diterapkan pada pokok bahasan yang berbeda sebagai upaya mengembangkan kemampuan berpikir kreatif dan hasil belajar siswa; dan (3) model discovery learning dijadikan sebagai model pembelajaran tematik karena model ini terbukti efektif dan inovatif untuk mengembangkan kemampuan berpikir kreatif siswa sesuai dengan tujuan Kurikulum 2013.

\section{DAFTAR PUSTAKA}

Al-Khalili, A. (2005). Mengembangkan kreativitas anak. Jakarta: Pustaka AL Kautsar.

Anugraheni, I. (2017). Analisa faktor-faktor yang mempengaruhi proses belajar guru-guru sekolah dasar. Jurnal Manajemen Pendidikan, 4(2), 205-212.

Anugraheni, I. (2017). Penggunaan portofolio dalam perkuliahan penilaian pembelajaran. Jurnal Pendidikan Dasar Perkhasa, 3(1), 246-258.

Arikunto, S. (2008). Penelitian tindakan kelas. Jakarta: PT Bumi Aksara.

Darmadi. (2017). Pengembangan model dan metode pembelajaran dalam dinamika belajar siswa. Yogyakarta: CV Budi Utama.

Depdiknas. (2006). Kurikulum tingkat satuan pendidikan (KTSP). Jakarta: Departemen Pendidikan Nasional.

Hanifah, U., \& Wasitohadi. (2017). Perbedaan efektivitas antara penerapan model pembelajaran discovery dan inquiry ditinjau dari hasil belajar IPA siswa. Jurnal Mitra Pendidikan, 1(2), 92-104.

Indriasih, A. (2015). Pemanfaatan alat permainan edukatif ular tangga dalam penerapan pembelajaran tematik di kelas III SD. Jurnal Pendidikan, 16(2), 127-137.

Kristin, F., \& Rahayu, D. (2016). Pengaruh penerapan model pembelajaran discovery learning terhadap hasil belajar IPS pada siswa kelas 4 SD. Scholaria: Jurnal Pendidikan E Kebudayaan, 6(1), 84-92.

Kristin, F. (2016). Analisis model pembelajaran discovery learning dalan meningkatkan hasil belajar siswa SD. Jurnal Pendidikan Dasar Perkhasa, 2(1), 90-98.

Maharani, Y. B., \& Hardini, I. T. A. (2017). Penerapan model pembelajaran discovery learning berbantuan benda konkret untuk meningkatkan hasil belajar IPA. Jurnal Mitra Pendidikan, 1 (5), 249-561.

Mawardi, H., dkk. (2014). Penerapan pembelajaran tematik untuk meningkatkan aktivitas belajar kelas I SD. Jurnal Pendidikan dan Pembelajaran, 3(7), 1-9.

Sani, R. (2014). Pembelajaran saintifik untuk implementasi kurikulum 2013. Jakarta: PT. Bumi Aksara. 